\title{
Adaptive Physical Education Learning During Pandemic in School for Children with Special Needs
}

\author{
Dwi Gansar Santi Wijayanti ${ }^{1}$, Wahyu Ragil Kurniawan ${ }^{2}$, Zaky Ilham Kurniawan ${ }^{3}$, Dian Arum \\ Setiowati $^{4}$ \\ \{dwigansarsanti@mail.unnes.ac.id ${ }^{1}$,wahyuragil@mail.unnes.ac.id, zakyilahamk9@ students.unnes.ac.id, \\ dianarum@students.unnes.ac.id\}
}

Universitas Negeri Semarang, Indonesia ${ }^{1,2,3,4}$

\begin{abstract}
There are various phenomena regarding learning during the pandemic, especially in adaptive physical education learning in school for children with special needs. The ability of adaptive physical education teachers to plan, implement, and evaluate learning is the key to expected learning outcomes. This study aims to analyze adaptive physical education learning during the pandemic in school for children with special needs. This is qualitative research conducted in three schools for children with special needs academic years 2020/2021. Data collection method using observation, interviews, and documentation. Data analysis through data reduction, presenting data and concluding the results. Adaptive physical education teachers have implemented the learning strategy. However, they have not been able to choose the correct learning method to be implemented in adaptive physical education learning during the pandemic. This research concludes that adaptive physical education learning during the pandemic has not been implemented optimally in school for children with special needs.
\end{abstract}

Keywords: Physical Education, Pandemic, Learning, Special Need.

\section{Introduction}

Education is a significant factor in improving the quality of human resources on earth [1]. Through education, we can form quality human resources and have high character. Physical education is essentially an educational process that utilizes physical activity to produce holistic changes in individual qualities, both physically, mentally, and emotionally [2]. Physical education is an integral part of education as a whole, which has 3 aspects of assessment, that is affective, cognitive, and psychomotor, by using physical activities to develop students' overall abilities from physical abilities, spiritual abilities, and health quality so that students have harmony in their development. Physically, mentally, and can interact socially well [4]. Adaptive physical education is an educational process through movement activities for the rate of growth and development both physically and psychologically in order to optimize all potential abilities, physical skills that are adjusted to children's abilities and limitations, intelligence, physical fitness, social, cultural, emotional, and a sense of beauty. In order to achieve the goal of education, namely the formation of a whole human being [5].

In his research, Gunawan said that the purpose of learning is not only to develop the skills of students, but to develop the students' personal development completely, so that the basic concepts and teaching models of physical education are important to be understood by educators to achieve an effective learning process [6] . Especially for students with special needs, where they are not yet fully independent. 
Implementing skills is the professional duty of the teacher in creating a system or carrying out teaching activities. There are three main tasks or activities in implementing teaching, namely: 1). Opening teaching, 2). Manage teaching activities and 3). Closing the teaching [7]. So that the role of adaptive physical education teachers is needed in the learning process. This is in line with research conducted by Ainin that in implementing adaptive physical education learning, a teacher needs to make good learning preparation so that the learning process can run smoothly [8]. Especially in this pandemic era, adaptive physical education teachers are increasingly required to be more creative and innovative in learning. It is because offline learning has changed to online learning. So learning objectives will be achieved if they receive support from various parties.

Boyolali Regency is one of the areas in Central Java Province which has many School with Special Needs, that is 11 schools. And there are 3 schools that have been accredited B, that is SMPLB YPALB Cepogo, SMPLB N Boyolali, and SLB YPCM Boyolali. Based on the preliminary observations that have been made, it is found that several diverse phenomena regarding adaptive physical education learning patterns. In terms of learning preparation, there is a mismatch between the lesson plan that have been made with the implementation of the learning for each category of disorder. In addition, there are teachers who prepare lesson plans at the end of the semester, not at each meeting. As well as reference materials and learning infrastructure are also very minimal provision.

This study aims to describe the patterns of implementation, implementation, and learning strategies in adaptive education used during the pandemic.

\section{Methods}

This research is descriptive qualitative. Creswell defines it as an approach or search to explore and understand a central phenomenon [9]. The results of qualitative research in the realm of education are descriptive. The purpose of qualitative research is to understand individual views, search for and explain processes, and explore in-depth information about a limited research subject or background [10].

The subjects of this study is physical education teachers at SMPLB YPALB Cepogo, SMPLB N Boyolali, and SLB YPCM Boyolali. In selecting research subjects, researchers used the purposive sampling technique. Purposive sampling is a "sampling technique with certain considerations" [11]. The choice of this subject is motivated because the purpose of this study is how the online learning process of adaptive physical education subjects and what factors support and hinder teachers in the online learning process for adaptive physical education teachers.

A good instrument will produce good data too. The instruments used in this study were interview guides, questionnaires, and documentation given to adaptive physical education teachers. The data collection technique is an activity carried out by researchers to obtain the data used in the study. The data collection techniques used in this study were interviews, questionnaires, and documentation. The type of interview used in this study was a structured interview. The type of questionnaire used in this study is an open questionnaire. An available questionnaire contains questions or statements that can be filled in freely by the respondent. Documents are records of past events. Documents can be in the form of writings, pictures, or monumental works of a person [12].

Data analysis used in this research is the analysis technique of Miles and Huberman. The activities in qualitative data analysis are carried out interactively and continue to completion so that the data is saturated. Data analysis has three activities: data reduction, display data, and 
conclusion drawing/verification. There are quite a lot of data obtained in the field at the data reduction stage, so it needs to be recorded carefully and in detail. Reducing data means summarizing, choosing the main things, focusing on important things, looking for themes and patterns, and removing unnecessary. Data that has been reduced will provide a clearer picture and make it easier for researchers to carry out further data collection and look for it if needed. At the data display stage, the aim is to make it easier for researchers to understand what is happening and plan the next steps based on what has been understood. The final stage is the conclusion drawing/verification in qualitative research may or may not answer the problem formulated at the outset. This happens because qualitative research is still temporary and will develop after the study is in the field.

The research procedure used in this research is divided into three stages, namely the prefield stage, the fieldwork stage, and the data analysis stage. At this stage, the pre-field step compiles a research design to understand the methods and techniques in research. Choosing a research field, exploring and assessing the field in the form of a field orientation with the aim and purpose that the researcher tries to get to know all elements of the social, physical and natural environment and the introduction of the field is also intended to assess the situation, situation, setting, and context whether there is suitability with the problem. Prepare research equipment in the form of equipment needed or used in research, such as research permits, stationery, and other equipment to support research. In the fieldwork stage, the researcher understands the research background first. Researchers need to prepare themselves to start researching to obtain data or information required in research. The data obtained came from questionnaires and interviews conducted with adaptive physical education teachers at the designated research sites. Researchers made an analysis to get more in-depth results regarding the online learning process carried out by adaptive physical education teachers during the pandemic and the supporting factors and factors that hinder teachers in implementing learning during the pandemic. After the data is obtained, the researchers compile data descriptively and in-depth so that the information that has been obtained can be appropriately studied. In the data analysis stage, in qualitative research, the data obtained comes from various data sources collected through multiple data collection techniques and is carried out continuously until the data is saturated. The researcher carried out the data analysis, that is processing the data collected and obtained in the field, both the form of informants and documents in the previous stage, then compiled into a study.

\section{Result and Discussion}

Based on the data obtained from open questionnaires and structural interviews, the results are:

1. Does your school use the 2013 curriculum?

"Yes, here has implemented the 2013 curriculum".

2. Do you carry out assessment activities for students as one of the initial strategies in adaptive physical education learning activities? "-."

3. What are your considerations in determining learning media during the pandemic period?

"During the pandemic, schools took a policy to eliminate the learning process. In this case, there is no distance learning activity. Learning media is only written in the lesson plan but not implemented. 
4. What are your considerations in determining learning methods during the pandemic period? "During the pandemic, schools took a policy to eliminate the learning process. In this case, there is no distance learning activity. The learning method is only written in the lesson plan. Still, it is not implemented."

5. How did you apply this learning method during the pandemic?

"In its application, distance learning is replaced with a home visit. Each teacher conducts a visit to each student's home to check their progress."

6. How are the facilities and infrastructure in schools that support adaptive physical education learning during the pandemic period?

"Facilities and infrastructure in the sports sector are very fulfilling, but during the pandemic, they were not used for learning activities."

7. What is the role of learning media in adaptive physical education learning during the pandemic?

"Even though I did not study during the pandemic, I understand one thing that learning media is essential to facilitate learning activities."

8. What is the learning system like during a pandemic?

"This school does not hold learning activities that are carried out remotely or online. We only held a home visit."

9. How do you apply the curriculum in learning activities?

"Yes. For the curriculum, we use the pandemic curriculum with several modifications, especially in lesson plans. The curriculum and lesson plans are still limited, like the curriculum during the pandemic."

10. How did you modify learning media during the pandemic?

11. How do you prepare lesson plans before implementing learning activities?

"I prepare my lesson plan at the beginning of the semester normally."

12. How was your preparation before carrying out adaptive physical education learning activities during the pandemic?

13. How did you prepare facilities and infrastructure for adaptive physical education learning activities during the pandemic period?

14. What evaluation tool did you prepare in the learning evaluation activity during the pandemic period?

"The evaluation tool is only contained in the lesson plan, but it is not implemented because there is no distance learning."

15. How do you understand adaptive physical education?

"Adaptive physical education is a part of physical education subjects specifically for students with special needs."

16. How is adaptive physical education implemented during the pandemic period in schools?

"There are no adaptive physical education learning activities during the pandemic period, given the conditions of students that make it impossible if distance learning is carried out."

17. How do you deliver material to students?

18. How do you use learning media in learning activities?

"The media used can be interactive video, audio, and pictures." 
19. How is the feedback of students on the delivery of the material that you have delivered?

20. How did you generate learning motivation for students during the pandemic?

"I collaborated and communicated with parents to remind students to continue learning and maintain health."

21. How did you provide services to students during the pandemic?

"The service is carried out by holding a home visit."

22. How did you apply the assessment techniques in adaptive physical education learning during the pandemic?

"The assessment technique is as stated in the lesson plan and syllabus."

23. How did you provide an authentic assessment of attitudes, knowledge, and skills in adaptive physical education during the pandemic?

24. What is the mechanism for scoring in attitudes, knowledge, and skills during the pandemic?

25. How did you apply the instruments that were prepared in the assessment activity?

26. How do you understand the abilities of each student, especially during the pandemic?

"Analyzing the results of the home visit that has been carried out."

27. How do you condition students in adaptive physical learning activities during the pandemic? "Cooperating with students' parents to supervise them while at home".

28. How do you develop the academic/non-academic potential of students?

"Continue to motivate students."

29. How do you communicate with students who are children with special needs?

"Taking an approach to get to know the character of each student."

30. How do you respond to parents or guardians of students who are critical of their child's development during adaptive physical education learning activities?

"Being open and candid when explaining and trying to understand the wishes of the parents of students."

31. What is your educational background?

"Physical Education Department of Semarang State University."

32. How did you design adaptive Physical Education teaching materials during a pandemic?

"Adjusted to the lesson plans that have been prepared".

33. How do you synchronize the curriculum with the material that will be delivered to students?

"The material contained in the curriculum is adjusted and adapted to the conditions of each student."

Based on the results of research with descriptive qualitative methods through data collection techniques in the form of questionnaires and interviews that have been conducted on physical education teachers in school for student with special needs, it can be concluded as follows: the learning strategy aspect that has not been fulfilled is the indicator of conducting an assessment and selecting learning media. Conducting assessments such as conducting assessment activities as an initial learning strategy have not been implemented by SLB YPCM Boyolali. Choosing learning media, such as taking into account before choosing learning media, has not been implemented by the SLB YPCM Boyolali.

The learning method aspect that has not been fulfilled is the indicator for selecting the learning method. These indicators are considered before determining the learning method that has not been applied by the SLB YPCM Boyolali and SMPLB YPALB Cepogo. The aspect of learning modification that has not been fulfilled is the learning media indicator. These indicators 
are like making modifications to learning media that the SLB YPCM Boyolali has not implemented.

The unfulfilled planning aspect consists of three indicators: lesson plan implementation, teaching preparation, and evaluation tool planning. Learning implementation plan indicators such as preparing RPP have been implemented in SMPLB N Boyolali, SLB YPCM Boyolali, and SMPLB YPALB Cepogo. SLB YPCM Boyolali has not implemented teaching preparation indicators such as preparation before learning. Evaluation tool planning indicators, such as preparing evaluation tools for attitudes, knowledge, and skills, have not been applied in the SMPLB YPALB Cepogo and SLB YPCM Boyolali.

Implementing learning that has not been fulfilled consists of two indicators: teaching techniques and the use of learning media. Teaching technique indicators such as implementing distance learning have not been implemented in SLB YPCM Boyolali. Indicators of using learning media, such as maximizing the use of learning media, have not been implemented by SLB YPCM Boyolali.

The unfulfilled aspects of the assessment consist of three indicators: the assessment aspect, the assessment technique, and the assessment instrument. Indicators of assessment aspects such as assessing aspects of attitudes, knowledge, and skills have not been implemented in SLB YPCM Boyolali. Indicators of assessment techniques such as aspects of attitude using observation, aspects of knowledge using task collection, and aspects of skills using practical activities have not been implemented by SLB YPCM Boyolali and SMPLB YPALB Cepogo. Indicators of assessment instruments, such as using instruments in evaluation activities, have not been implemented by SLB YPCM Boyolali and SMPLB YPALB Cepogo.

The aspect of teacher competence, which consists of three indicators: pedagogical competence, professional and social competence, has been fulfilled by all SMPLB in Boyolali Regency.

The learning process is related to learning strategies and teacher competence in implementing learning. Before carrying out the learning process, the first steps that a teacher must take are selecting, deciding and considering the materials, procedures, methods and media used to achieve learning objectives through movement activities. When designing learning for students with special needs, the teacher must find and know the unique needs of each type of disorder that exists by students. So that education for children with special needs must be able to make modifications to meet students' educational needs. These modifications will be fulfilled in order to develop learning strategies that will later support the learning process.

Seeing the learning strategies in adaptive physical education during the pandemic period in SMPLB in Boyolali Regency, it can be said that the implementation of learning strategies has not been fulfilled in the adaptive physical education learning process, because there are still some indicators that have not been applied in some schools.

In determining the learning strategy, two activity indicators need to be considered: conducting an assessment and selecting learning media. Before determining the appropriate learning media for students with special needs, an assessment should be carried out first. The assessment is carried out to categorize each student's needs, which will make it easier for teachers to choose learning media. Indicators of assessing and selecting instructional media have not been implemented in SLB YPCM Boyolali. During the pandemic, the school did not organize a learning process either online (distance learning) or offline. The aspects of the learning method used by teacher to create an atmosphere of learning process so that students achieve basic competencies from indicators. The selection of learning methods is adjusted to the students' situation and conditions, as well as the characteristics of each indicator and competency to be achieved in adaptive physical education subjects. Given the importance of the 
learning method in teaching and learning activities, it is necessary to consider the appropriate learning methods for children with special needs as a teacher.

Indicators for selecting learning methods in the aspect of learning methods have not been fully fulfilled because they have not been implemented by SLB YPCM Boyolali and SMLB YPALB Cepogo. SLB YPCM Boyolali has not considered the learning method media because the school did not carry out a process of teaching and learning activities during this pandemic. Indicators for selecting learning methods have not been implemented in the SMPLB YPALB Cepogo because those who play an essential role as learning companions during the pandemic or distance learning are the parents/guardians of the students. The teaching method is entirely up to the parents/guardians of the students, remembering those who better understand their child's condition.

Education for children with special needs must be able to make modifications so that the educational needs of students are met, the skills provided are fully functional and mastered, and all members of the activity can fully participate. The learning modification aspect consists of three indicators: facilities and infrastructure, curriculum, and learning media. The indicators that have not been fulfilled are learning media, where the teacher makes modifications to the learning media. Learning media used in teaching and learning activities must be made according to students' needs following the disability category. Modifications to learning media have not been implemented in SLB YPCM Boyolali, considering that it did not organize learning activities during the current pandemic.

Teachers play an essential role in providing learning to students. The teacher's ability to manage adaptive physical education learning starting from the planning stage, the implementation stage, to the evaluation stage in learning greatly determines whether or not the learning objectives are achieved. Detailed planning is needed in providing physical education learning to students with special needs. Teachers must be able to determine methods, strategies and formulate appropriate evaluation forms by the conditions of the disabilities of each student. The provision of materials, teaching materials, and infrastructure is also needed to support adaptive physical education learning.

The planning aspect consists of planning the implementation of learning, teaching preparation, preparing facilities and infrastructure, and planning evaluation tools. All SMPLB has fulfilled the indicators for the preparation of the Lesson Plan in the Boyolali Regency. The preparation of a learning implementation plan is an essential point in the learning process because the plan is a reference for implementing the teaching and learning process in the classroom so that it can run more effectively and efficiently. Every teacher in an education unit is obliged to compile a complete and systematic Lesson Plan so that learning provides sufficient space for students to be creative and develop their talents and interests and physical and psychological development.

The preparation of the lesson plan has been implemented by all the adaptive physical education teachers concerned. However, in its implementation, there is a mismatch between the lesson plan and the learning activities. This is due to adjustments to the material and media prepared with the conditions of students in the field. In his research, Ega Trisna Rahayu suggests that a learning implementation plan is prepared for every meeting and ideally prepared at the beginning of the school year or before the learning process begins [13]. This condition has been met in all SMPLB in Boyolali Regency.

The following planning activity is to make teaching preparations. Teaching preparation is an essential element for the success of learning in the classroom. This preparation can be in the form of planning learning materials, media, and learning methods. Learning material planning must be tailored to the needs of students by considering various factors. According to 
Beltasar Tarigan that in determining adaptive physical education learning materials, it is necessary to consider the recommendations and diagnoses of doctors who treat children with special needs and the types of sports that are most popular In addition to the material, there is also a need for the preparation of learning methods and strategies, both of which are arranged in a variety of ways and according to the material to be delivered and adjust to the conditions of the learners [14]. Teaching preparation was not implemented in SLB YPCM Boyolali because the school did not organize learning activities during the pandemic period.

Planning for supporting facilities and infrastructure in learning activities is carried out by considering the availability of the media itself and the students' conditions. Facilities and infrastructure such as supporting equipment for physical education learning activities are available in all SMPLB in Boyolali Regency. School also provides internet packages for teachers of Rp. 50,000 and Rp. 25,000 for students, which are used to support distance learning activities during the pandemic. The hope is that learning activities can run smoothly.

Evaluation tool planning is carried out by preparing evaluation tools from three aspects: attitude, knowledge, and skills. Physical education teachers should have planned in advance the evaluation tools to use. The evaluation tool used to assess the attitude aspect is in the form of an observation sheet, the knowledge aspect is the assignment, and the skills aspect is using practice. SMPLB N Boyolali only fulfils the indicator for planning evaluation tools. In conducting the assessment, SMPLB YPALB Cepogo did not prepare such an evaluation tool. Although the results assessed are in the form of assignments and practices, the evaluation tool planning has not been applied.

The implementation of learning is the core of the learning process, including preliminary activities, core, and closing activities. In this study, the implementation of learning uses material mastery indicators as a form of preliminary activity, teaching techniques, and media as a form of core activity. During this pandemic, learning activities were replaced in the form of online or distance learning. Mastery of the material includes the teacher's ability to understand the nature of adaptive physical education and the material taught to students.

Mastery of the material is essential in the learning process because it will determine the success or failure of a teaching and learning activity. The teacher is the spearhead in improving the quality of learning in the classroom so that to be able to teach well, and a teacher must master the material to be taught. All SMPLB has implemented material mastery indicators in Boyolali Regency. Even though SLB YPCM Boyolali did not carry out distance learning during this pandemic, adaptive physical education subject teachers could master the material contained in the lesson plans that had been compiled.

Teaching technique is a method or strategy used by teachers to achieve maximum results during teaching. The teaching techniques used during this pandemic are different from those used before the pandemic. Before pandemic learning was carried out face-to-face, pandemic learning was carried out remotely or commonly known as online or in a network. Distance learning is formal education where group learning systems are separated and interactive communication systems are used for learners, learning resources, and instructors [15].

Distance learning has been implemented in SMPLB N Boyolali and SMPLB YPALB Cepogo. SLB YPCM Boyolali does not apply distance learning because it sees students' conditions that are not possible. Disabilities experienced by students are considered difficult for teachers in conditioning when learning takes place. Even so, the adaptive physical education teacher at SLB YPCM Boyolali still conducted a home visit to control each student's development and condition. Besides, adaptive physical education teachers also issued warnings or appeals to stay healthy during this pandemic. 
Physical education teachers carry out the use of instructional media in distance learning by considering the media's availability with the condition of the students. Indicators of the use of learning media have been implemented by SLB N Boyolali and SMPLB YPALB Cepogo. In learning activities, there is a modification of learning media. Physical education teachers provide parents/ guardians with opportunities to maximize media use during distance learning. The media used does not have to be the same as it should be in the teaching materials or material books. However, it is adjusted to the students' conditions to carry out adaptive physical learning smoothly. Modification of learning media can be replacing large basketball balls with plastic balls or paper balls that do not burden students. The essential thing in this learning, students are willing and able to move regardless of the media used.

Assessment is a series of activities to obtain, analyze, and interpret data about students' process and learning outcomes, which are carried out systematically and continuously so that it becomes meaningful information in decision-making [16]. Assessment of the achievement of basic competencies of students is based on indicators. Indicators in this aspect include aspects of assessment, assessment techniques, and assessment instruments. Assessment of student learning outcomes in primary and secondary education includes aspects of attitudes, knowledge, and skills.

An attitude assessment is an activity carried out by the teacher to obtain descriptive information about students' behavior. Knowledge assessment is an activity carried out to measure students' mastery of knowledge. Skills assessment is an activity carried out to measure students' ability to apply knowledge in performing specific tasks. Indicators for assessing attitudes, knowledge, and distance learning skills have been implemented in SLB N Boyolali, SMPLB YPALB Cepogo. SLB YPCM Boyolali was not fulfilled in this aspect because it did not organize distance learning activities.

The assessment technique used is the process and outcome assessment. Assessment of the learning process uses an authentic assessment approach. Evaluation of the learning process is carried out during the learning process, which is used to assess aspects of attitude. Attitude aspect assessment can use the observation sheet. Assessment of learning outcomes is carried out during the learning process and at the end of learning. Assessment of the knowledge aspect is carried out by collecting assignments, while the skills aspect uses practical activities. This kind of assessment technique has been applied in SLB N Boyolali. In distance learning practice, physical education teachers conduct attitude assessments via electronic media, assessing knowledge and skills through assignment collection by students. Students submit assignments to the teacher in the form of videos. Like SLB N Boyolali, SMPLB YPALB Cepogo also used the same technique in the assessment process. The difference lies in the attitude assessment where SMPLB YPALB Cepogo conducts attitude assessment with tolerance assessment.

Law No. 14 of 2005 on teachers and lecturers explains that a teacher must possess four competencies: pedagogic, professional, personality, and social. Pedagogic competence is the ability to manage student learning, evaluate learning outcomes, and develop students to actualize their various potentials. Pedagogic competencies in this study include teachers' ability to find ways to understand students' abilities, the ability to condition students, and the ability to develop academic/non-academic potential. All SMPLB has fulfilled indicators of pedagogic competence in Boyolali Regency. Even though they did not hold distance learning during the pandemic, physical education teachers at SLB YPCM Boyolali had abilities related to their pedagogical competencies.

Professional competence is the ability to master learning material broadly and deeply, enabling it to guide students to meet competency standards. Professional competence in this research is the educational background of physical education teachers, compiling learning 
materials according to the lesson plans, and synchronizing the curriculum. All SMPLB fulfills indicators of professional competency aspects in Boyolali Regency.

Social competence is the ability of educators to communicate and interact effectively with students, fellow educators, education personnel, parents/guardians of students, and the surrounding community. Social competence in this study includes the teacher's ability to communicate with students and parents. All SMPLB has fulfilled indicators in the aspect of social competence in Boyolali.

\section{Conclusion}

During the pandemic in SMPLB Boyolali Regency, the adaptive physical education learning pattern was carried out online or better known as distance learning. This learning pattern is only applied at SLBN Boyolali and SLB YPALB Cepogo.

Implementing adaptive physical education learning during the pandemic that has been implemented in SLBN Boyolali and SLB YPALB Cepogo has been running well, as seen from the fulfillment of several aspects: adaptive physical education learning planning activities, implementing adaptive physical education learning and adaptive physical education learning assessments.

The adaptive physical education learning strategy in SMPLB Boyolali Regency has been fulfilled, seen from the formulation of learning strategies before carrying out learning activities, modifying learning methods, learning media, and learning activities.

Acknowledgments. This research was funded by the Faculty of Sports Sciences, Universitas Negeri Semarang.

\section{References}

[1] Mustafa, P. S., \& Dwiyogo, W. D. (2020). Kurikulum Pendidikan Jasmani, Olahraga, dan Kesehatan di Indonesia Abad 21. JARTIKA Jurnal Riset Teknologi Dan Inovasi Pendidikan, 3(2), 422-438.

[2] Nurkusuma, T. W. (2017). Penerapan Permainan Kecil Terhadap Motivasi Belajar Siswa Dalam Pembelajaran Pendidikan Jasmani, Olahraga Dan Kesehatan Pada Siswa Kelas V Sdn Babatan 5 Kecamatan Wiyung Surabaya. Jurnal Pendidikan Olahraga dan Kesehatan, 5(1).

[3] Lusianti, S., Kholis, M. N., \& Puspodari, P. (2019). Profil Proses Pembelajaran Pendidikan Jasmani Adaptif Anak Tunawicara Di Sdlb Se-Kabupaten Kediri.

[4] Gayuh, Hutomo. 2016. "Survei Pelaksanaan Pembelajaran Pendidikan Jasmani Adaptif di Sekolah Dasar Luar Biasa (SDLB) se Kabupaten Semarang Tahun 2016”. Skripsi: Prorgam Sarjana Pendidikan Jasmani, Kesehatan dan Rekreasi Universitas Negeri Semarang.

[5] Taufan, J., Ardisal, A., Damri, D., \& Arise, A. (2018). Pelaksanaan Pembelajaran Pendidikan Jasmani Adaptif bagi Anak dengan Hambatan Fisik Motorik. Jurnal Pendidikan Kebutuhan Khusus, 2(2), 19-24.

[6] Gunawan, Fakih. "Survei Pelaksanaan Pembelajaran Pendidikan Jasmani Adaptif Sekolah Dasar Luar Biasa Se Kabupaten Gunungkidul”. Journal of Phisical Education, Sport, Health and Recreations. 2014

[7] Suntoda, A., Andriyani, S. V., \& Vidia, S. (2012). Kemempuan Guru Pendidikan Jasmani Adaptif Dalam Melaksanakan Program Pembelajaran Di SLB Bagian A Kota Bandung.

[8] Ainin, I K. "Strategi Pembelajaran Pendidikan Jasmani Adaptif (penelitian pada Guru Pendidikan Jasmani Adaptif Sekolah Dasar Inklusif Kota Surabaya) “. JASSI. Volume 10, Nomor 2, 2011:149-164. 
[9] Liem, I., Semiawan, T., \& Brajawidagda, U. (2010). Tugas Akhir Program Diploma III Bidang Teknologi Informasi dan Komunikasi. JURNAL INTEGRASI, 2(2), 1-7.

[10] Putra, N. (2013). Metode Penelitian Kualitatif Pendidikan. Rajawali Pers.

[11] Sugiyono. (2015). Metode Penelitian Pendidikan (Pendekatan Kuantitatif, Kualitatif, dan R\&D). CV Alfabeta

[12] Sugiyono. (2014). Memahami Penelitian Kualitatif. CV Alfabeta

[13] Rahayu, E T . 2013. Strategi Pembelajaran Pendidikan Jasmani Implementasi Pada Pembelajaran Pendidikan Jasmani, Olahraga, dan Kesehatan. Bandung : Alfabeta

[14] Beltasar Tarigan. 2000. Penjaskes Adaptif. Jakarta : Departemen Pendidikan Nasional Direktorat Jenderal Pendidikan Dasar dan Menengah Bagian Proyek Penataan Guru SLTP setara D-III Tahun 2000.

[15] Pateni, P. (2016). FOUNDATIONS OF DISTENCE EDUCATION (Review Simonson. Jurnal TEKPEN, 1(3).

[16] Ayi Suhaerman.'Implementasi Kurikulum Baru Tahun 2013 Mata Pelajaran Pendidikan Jasmani (Studi Deskriptif Kualitatif pada SDN Cikarang)". Jurnal Mimbar Sekolah Dasar. Volume 1 Nomor 1, 2014:71-76. 